\section{James Rosenau and Monica Lewinsky}

Throughout the Clinton-Lewinsky scandal, media pundits and commentators puzzled and despaired that Americans were not more outraged at their president's behavior (Kurtz 1998). Opinion poll after poll showed that most Americans believed the president had an affair with the White House intern and lied about it, gave Clinton very high approval ratings, and disapproved of the House members conducting the impeachment trial. How could Americans give high ratings to an admitted lecher, liar, and adulterer? What were Americans' values? Was Clinton the new "Teflon President?" Why? My colleagues and I at the Catholic University of America fielded numerous queries from reporters who could not reconcile the public's reaction to the scandal with the rise of the Christian Right, Promise Keepers, and the Million Man and Million Woman Marches.

After much deliberation, I have concluded that a theory advanced by James Rosenau, an international relations theorist from George Washington University who studies changes in the system of sovereign states, can lead to an explanation of the U.S. public's reaction.

Rosenau (1990, 1995; Rosenau and Fagen 1997) has contended that globalization and the spread of technology has made citizens more skillful in gathering and using a variety of information and analyzing how it affects them. This information and skills revolution has changed the nature of political authority. As regimes in China, Nigeria, Indonesia, and South Africa have learned, citizens are becoming less deferential to traditional sources and claims of authority and legitimacy and are paying more attention to the performance of their leaders. According to Rosenau, citizens are beginning to judge the legitimacy of state leaders not by whether they adhere to moral or spiritual standards (traditional legitimacy claims), but by competence.

During the Middle Ages, church and state used to compete for the allegiance (and taxes and military service) of citizens. Sovereignty, or the system of having only one source of political control or authority over one piece of territory, was a rejection of the church's claims of jurisdiction. The church may have sway over all men's souls, the Treaty of Westphalia admitted in 1648, but only one sovereign could govern the people in any specific territory. In an economic system where labor, capital, and the means of production were fixed, control over territory was critical and at the heart of sovereignty. Now, in a global economy in which goods, technology, labor, and capital flow easily over borders, control over territory is less important. Not only are borders now more porous and less important, but territory is less important in the pursuit of wealth. Small states like Japan can do well in a service and information-based economy, whereas land-rich states like Russia or even reunified Germany may find that size actually hinders performance.

Not only is sovereignty becoming less dependent on territory, the nature of claims to allegiance are changing. Leaders can no longer rely on habit or tradition as the basis of their claims to legitimacy. As capitalism, democracy, and technology spread around the globe, leaders doing a poor job of running their countries can neither hide nor defend their records. Inadequate performance causes international investors to pull out, as happened during the recent Asian economic crisis, and regime's like Suharto's in Indonesia find themselves crippled and toppled without a single shot being fired.
On the flip side, good performance, such as turning budget deficits into historic surpluses and presiding over a period of unprecedented economic growth without inflation, can boost the legitimacy of an administration literally caught with its pants down. Twenty-five years ago, Nelson Rockefeller's divorce or Eagleton's psychiatric counseling were enough of a challenge to political legitimacy to keep these candidates off their party's presidential tickets. However, in a competitive globalized economy where efficiency and the economic bottom line are prized above all, job performance counts more than traditional claims to legitimacy. The president can sully whomever's dress he wants as long as his economic record is clean. In 1992 in New Hampshire, Republicans raised the Gennifer Flowers flag and believed they had killed Clinton's candidacy; the Clinton team looked at the changing global economy, didn't blink, and retorted, "It's the economy, stupid." Seven years later, conservatives, many Republicans, and the media still don't get it. But, following Rosenau, it is easy to see there is nothing special about Clinton that allows him to get away with his transgressions. In a globalized economy, analytically skillful citizens judge political legitimacy by performance, not morality. Clinton's presidency was not saved by the liberal media, the apathetic public, the demise of traditional family values, or even Larry Flint. Rather, the Internet, foreign direct investment, and an interdependent economy that has radically altered citizens' needs, perceptions, and relation to political authority saved Clinton. Globalization trumped Monica Lewinsky, as James Rosenau could have told you it would.

Maryann K. Cusimano Catholic University of America

\title{
References
}

Kurtz, Howard, 1998. "Public Declines to Share Media's Sense of Betrayal." The Washington Post, September 15, A10.
Rosenau, James N. 1990. Turbulence in World Politics. Princeton: Princeton University Press.

\footnotetext{
. 1995. "Sovereignty in a Turbulent World." In Beyond Westphalia? State Sovereignty and International Intenention, ed.
} 
Gene M. Lyons and Michael Mastanduno. Baltimore: Johns Hopkins University Press.

_- and Michael Fagen. 1997. "A New Dynamism in World Politics: Increasingly Skillful Individuals?" International Studies Quarterly 41(December): 655-86.

\section{Kansas Press Should Have Been Ranked}

In a trademark case, Judge Learned Hand declared that "reputation, like a face, is the symbol of its possessor and creator." Goodson, Dillman, and Hira's flawed article in the June 1999 issue of $P S$, "Ranking the Presses: Political Scientists' Evaluations of Publisher Quality," has struck a clumsy and undeserved blow against the University Press of Kansas's reputation as a publisher of books in political science. For reasons unknown to me, though I have sought from the authors an explanation, the investigators deviated from their stated methodology and omitted the University Press of Kansas from the survey list of 65 publishers. We published ten or more new political science books in 1997, we're not a niche publisher, and we publish books as our primary "products"-thus meeting all of the criteria for inclusion on the survey list.

Correcting a mistake of this sort in this kind of forum is akin to shutting the barn door after old Bessie has escaped. I ask myself if it really helps to assert that our lists in the presidency, urban politics, American political theory, legal and constitutional studies, and public policy are very highly regarded by political scientists if judged by sales, reviews, course adoptions, book prizes, and anecdotal feedback. In the end, I suppose, the University Press of Kansas will have to depend upon its political science books and their authors and readers speaking more memorably and convincingly than this misleading excursion into reputational rankings.

Fred Woodward University Press of Kansas

\section{It's About Quality, Not Prestige}

In their 1983 PS article, "What Do the New Ratings of Political Science Departments Measure?" (15[Summer]: 532-39), Welch and
Hibbing asked a question I am tempted to ask about the recent poll conducted by Larry Goodson, Bradford Dillman, and Anil Hira, the results of which appeared in this journal as "Ranking the Presses: Political Scientists' Evaluations of Publisher Quality" (32[June]: 25762). What, indeed, does this poll measure?

I don't doubt that the poll is, in some way, a measure of the perceived prestige of the publishers included in the ranking. But is it a true measure of the quality of political science books? Let me explain why I think this ranking should not be taken as a good indicator of the quality of the books published by these presses.

I served for 20 years as the acquisitions editor for books in political science at Princeton University Press (ranked \#2); almost all books issued by that press between 1970 and 1990 in political science were ones I acquired. In mid-1989 I became director of the Penn State Press (ranked \#41), which had done very little publishing in political science prior to my arrival-and which had overall won only four prizes for books published during its entire history since 1956. Since 1990, the press has won forty book prizes, including eight for books in political science (see www.psu.edu/psupress/news/ news_main.html). This indicates our procedures for reviewing manuscripts and our methods of acquiring them differ in no significant way from those I pursued at Princeton. Book for book, I do not see any less enthusiasm or strong endorsements from reviewers for the books we publish here than for those I acquired at Princeton.

If there is no real difference in "quality control," then how may one account for the large discrepancy in the ranking of Princeton and Penn State? It's quite simple, actually. First, Princeton has been publishing political science books much longer than Penn State and, thus, has a track record that gives it an appreciable advantage when the programs are compared. Moreover, an Ivy League press derives prestige from its association with its parent institution. Second, Princeton is a much larger press. Its overall annual output averages around 200 titles, whereas Penn State's output averages 70 . Princeton, by virtue of its size, is able to publish in a wider range of subfields than Penn State. While we cover all four major areas-American politics, comparative politics, international relations, and political theory - we concentrate more in political theory and comparative politics (but do not publish any African or Asian politics titles). Not surprisingly, then, scholars in the fields we do not cover, or cover only thinly, will not be impressed with Penn State's output. Third, it is probably true that we publish fewer of the most senior and best known scholars at Penn State than does Princeton, partly because we do not have the money to bid for the most high-profile books. But I do take great pride-as I did at Princeton-in publishing the work of promising young scholars. I feel confident that a good many of the firsttime authors whose books we have published at Penn State over the past decade will emerge as leaders in their subfields.

It will, of course, take time for the merits of these young authors' works to be fully recognized, and I cannot complain too loudly that perceptions among political science scholars have generally not kept pace with the reality of change. Or that the more-established presses clearly have an advantage, in any such ranking over presses whose programs are undergoing revitalization. I do not challenge the right for the high-ranked presses to be where they are.

I would hope, however, that in any future polling of this kind a more discriminating approach be taken. First, I think it muddies the waters to rank commercial textbook publishers alongside commercial and nonprofit publishers of works of original research in the same poll. How can one really compare, say, McGraw-Hill, a textbook publisher, with Princeton University Press, a publisher of original scholarship? This is like comparing apples and oranges: The "quality" being judged is quite different. Second, it would 
be more revealing-and more true as a measure of quality- - to poll scholars about the ranking of publishers in their separate subfields.

This would prevent discrimination against smaller publishers that necessarily must concentrate on a narrow range of subfields and would provide a more sound guide to publication quality for tenure and promotion committees.

Lest I be accused of writing this letter too much out of self-interest, I also want to object to the authors' application of their own criteria in selecting publishers to be included in the ranking in a way that was not detrimental to Penn State but to other publishers. In particular, while acknowledging in a footnote that some of their respondents urged the authors to include the University Press of Kansas, they do not list this press in their table in spite of the fact that the criteria they used were "attendance and exhibits at major academic mectings and advertising in publications like the American Political Science Review." Kansas more than qualifies on these criteria. It has for years taken a double booth at APSA's Annual Meeting and advertised prominently in the APSR. It is a perfect example of a press that for business reasons, and to its credit, has chosen to concentrate its efforts in one subfield, American politics, and become one of the very best publishers in its area. It frankly astounds me that Kansas could have been left out of the poll when, in American politics at least, it surely deserves to be ranked near the top.

Sanford G. Thatcher Penn State Press

\section{Response to Critics of "Ranking the Presses"}

Studies that present rankings always provoke controversy, especially when the subject being ranked has not undergone such analysis before. As with any attempt to break new ground, we faced the problem of simultaneously creating valid indicators while also gathering data from, in this case, a representative sample of political scientists. Our aim was to see if our colleagues in the disci- plne had clear perceptions of publisher quality and, if so, what they were. These perceptions may differ from reality. As Sanford G.

Thatcher notes, differences in ranking may have much more to do with institutional prestige, press size, and length of time publishing in political science than the actual quality of the books published. We concur, but as we point out in our article, we did not attempt to gather data on why our respondents' ranked presses as they did. We focused on discovering whether there was a clear pecking order, as it is our strong belief that general perceptions of press reputation are taken into account when high-stakes decisions are made about people's careers. Over time and within particular specializations there certainly will be variations of reputation. Moreover, reputation is not the only criterion by which to judge a publisher-as we acknowledged by including our familiarity index. However, the strong responses to our survey, both positive and negative, confirm that general reputation does matter.

When we began this study, we quickly found that there were far too many publishers for us to include in our survey. Our aim became to include only the largest and most versatile publishers who would be known by political scientists in all subdisciplines. Our data on responses by subdiscipline, not reported in our article, show strong consistency in publisher reputation. Undoubtedly, that consistency would have been reduced (and our knowledge increased) had we included the numerous meritorious publishers, such as the University Press of Kansas, that publish primarily in one subfield. However, we decided not to include many of these publishers in order to keep our survey a manageable length.

Our cutoff point for inclusion, if all other criteria were met, was whether a publisher produced 10 or more new political science books in 1997. Our method of verification, which worked fine in virtually all cases, was simply to visit individual publisher web sites and see how many political science books they announced as published in 1997. Where a web site was unclear or unavailable (as in the case of Kan- sas), we looked at the number of publications listed for that publisher on the Association of American University Presses (AAUP) web site. For example, a search of the AAUP site on September 9, 1999, revealed that the University of Chicago Press has more than 100 titles in political science (14 new in 1997), while the University Press of Kansas has 43 titles (none from 1997). We did not contact publishers directly to ask them about their lists, as we did not wish to potentially bias our survey results by providing those who would be most interested in the outcome with advance knowledge of our activity. We did ask our respondents, both as part of our presurvey testing and our actual survey, for suggestions about presses that should be included. As noted in our article, the University Press of Kansas was the most frequent recipient of "write-in votes" in the survey.

Finally, we agree with Sanford Thatcher that more nuanced and perhaps satisfying results could be obtained with a survey that divides publishers by different subtypes or subfields and that polls scholars by subfields. This is a more complex issue methodologically, especially given the constraints that caused us to conduct this research over the Internet. Moreover, it would not allow for comparison of all publishers on the basis of their general reputations. Our survey confirms that some commercial publishers have excellent reputations. This is not a matter of comparing apples and oranges, since not all textbooks are devoid of original research, nor is all original research that is published of no classroom use. Thus, we conclude that publishers have general reputations, that we could and did measure these, and that conducting such research via the Internet is possible. Nonetheless, we invite our creative and methodologically sophisticated colleagues throughout the discipline to conduct more focused analyses to improve upon our initial foray into this area. A Wuffle, where are you?

Larry P. Goodson

American University in Cairo Bradford Dillman Koç University Anil Hira Tulane University 


\title{
LYNNE RIENNER PUBLISHERS
}

\author{
UNDERSTANDING: \\ INTRODUCTIONS TO THE STATES AND REgIONS OF THE CONTEMPORARY WORLD \\ SERIES EDITOR: DONALD L. GORDON
}

\section{Understanding Contemporary Latin America}

edited by Richard S. Hillman

"L political differences that make its study a daunting task for new students of Latin America. Yet
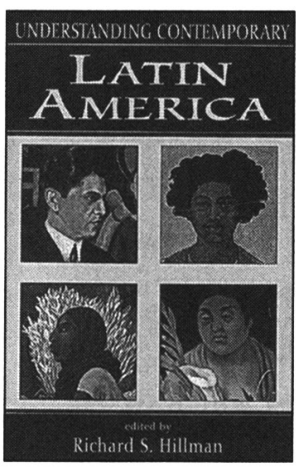

Hillman's edited volume masterfully unravels many issues facing Latin America today to enrich our understanding of its complex dynamics."

$$
\text { -Cynthia Chavez Metoyer }
$$

“E America.' It will be useful not only in introductory survey courses but also in courses on politics, economics, and history."-James Dietz $1997 \cdot h c \$ 49.95 \cdot p b \$ 22$

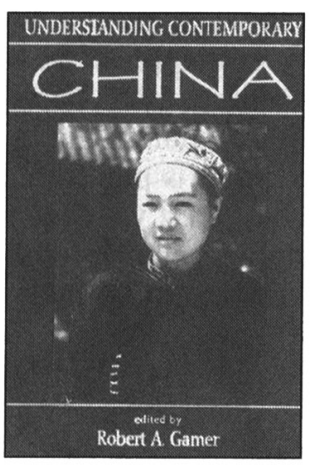

\section{Understanding Contemporary China} edited by Robert E. Gamer

A lucid and well-grounded assessment of the most crucial issues affecting China today. Written in an engaging and accessible manner,

Understanding Contemporary China reveals the complexity of China's challenges at the end of the twentieth century, their global impact, and the prospects for the future of the country. • $1999 \cdot h c \$ 55 \cdot p b \$ 22$

\section{Understanding the Contemporary Middle East}

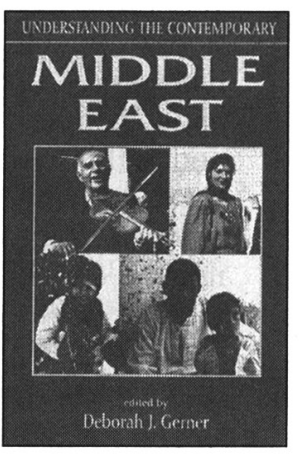

edited by Deborah J. Gerner

"No comparable work is available.... The breadth and depth of coverage, the analysis of current and historical events, and the expertise gathered in one volume succeed in making understanding the Middle East that much easier."

\section{$\rightarrow$ Denis J. Sullivan}

December $1999 \cdot b c \$ 55 \cdot p b \$ 22$

\section{ND EDITION}

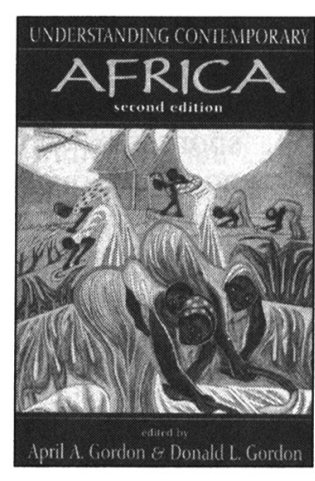

Understanding Contemporary Africa edited by April A. Gordon and Donald L. Gordon

\section{"Excellent.... a remarkably sound text for introductory courses on Sub-Saharan Africa." \\ $\neg$ Journal of Developing Areas}

“A
"Whereas each of these chapters can be treated as a distinct and separate entity, they also form a well chosen and integrated whole.... deserving of a prominent place in university programmes."
—Canadian Journal of Development Studies
$1996 \cdot p b \$ 22$

